\title{
Religion, Gullibility, Health and Well-being: The Case of Traditional Healers in Harare, Zimbabwe
}

\author{
Tabona Shoko \\ ORCID iD: https://orcid.org/0000-0002-0093-4570
}

\begin{abstract}
The hyperinflationary whirlwind that has gripped Zimbabwe since 2000 has seen a sharp decline in bio-medical facilities and the resurgence of traditional and faith healers. As a result, a number of people have fallen prey to fake traditional healers and prophets. Most of these practitioners have made off with people's money. The law has been so compromised through corruption and negligence, such that most of the fraudsters have escaped without prosecution. While we acknowledge that some of these healers and prophets are genuine and do assist people, there are others who are only there to fleece ignorant people. The recourse to gullible means by the traditional healers and their clients has been exacerbated by exorbitant fees charged by some unscrupulous health practitioners in hospitals. This has resulted in the sprouting of traditional herbal practitioners at a number of public places in the streets. The motive by the clients has been to seek alternative health services that they regard as cheaper and affordable. However, the clients have ended up being vulnerable to duping by some fake traditional healers. This paper seeks to explore the phenomenon of traditional herbal practitioners under the banner of traditional medicine in Zimbabwe. Based on empirical data, the paper argues that both the herbal vendors and their clients are gullible in the use of traditional medicine in Harare, Zimbabwe. The traditional healers are but fake practitioners, shrewd and cunning business entrepreneurs who fleece innocent people of their income in a depressed economic environment in Harare.
\end{abstract}

Keywords: gullible, traditional healers, herbs, prophets, fake, health, medicine 


\section{Introduction}

Traditional medicine has always been at the heart of most rural African people, in particular the Shona people of Zimbabwe (Shoko 2010: 85). Of late traditional medicine has gained popularity in the cities and towns in Zimbabwe. The fact that most of the medicine is found within the vicinity of the urban environs makes it very attractive, user friendly as well as it being cost effective and flexible in adapting to the dynamics of modern trends, thus becoming a darling to many people. This paper examines how traditional healers have exploit people in the use of traditional medicine in Harare, Zimbabwe in the face of rapid socio-economic and political decline and deteriorating health and well-being of the people. The paper will first do a reappraisal of traditional medicine in Zimbabwe. Then it will explain the phenomenon of roving traditional healers and herbal medicine and its utilization in Harare before it assesses its efficacy.

Zimbabwe's economy has shrunk significantly after the 2000's land reform, resulting in severe hardships for the people. By the beginning of 2009, Zimbabwe's annual inflation had plummeted to 231 million percent (ZIMSTAT 2009). The macro-economic conditions in the country created untold hardships for the population. The most acute problems were shortages of basic commodities such as fuel, foreign currency, electricity, etc. Basic amenities were equally affected, resulting in the outbreak of diseases such as cholera that killed approximately 1700 people, and anthrax that saw the loss of livestock (Zimbabwe Situation 30 June 2016). The source of problems has been a subject of controversy in local and international circles. Whilst the Zimbabwe government attributed the problems to economic sanctions imposed upon the country after the 2000 land reform programme, the international critics accused Zimbabwe's government of engineering chaotic land reform and poor governance. After brief economic relief coming from a government of unity in 2013, today the country is plunged into another economic chaos due to disputed 30 July elections. The economic plunge has been due to extortionate taxes, unchecked price escalations and shortages of foreign currency, fuel and food. However, it is outside the purview of this paper to track all details pertaining to the debates over the political and economic crisis. It suffices to say that the health sector has not been spared the economic turbulence.

The escalating cost of living and shortages of medicines in hospitals have left the common person vulnerable to diseases and death. On average, the 


\section{Tabona Shoko}

lifespan of Zimbabweans has been reduced from 65 to 35 (The Insider 5 September 2018). Caught in this Catch 22 situation, three medical options have emerged that try to address the health needs of the people. These are biomedicine, faith healing practised by independent and Pentecostal churches, and traditional medicine. Whilst bio-medicine was introduced by Western medical practitioners at hospitals in the 1890s during times of colonization, faith healing was a by-product of the amalgamation of mainline Christianity propagated by missionaries and traditional culture. Traditional medicine has had a long history of existence prior to modernity, but has been widely practised in rural areas in Zimbabwe. The shortfalls of biomedicine due to spiralling costs and exorbitant consultation fees charged by some faith healers have seen the multiplication of traditional medicine in cities like Harare in Zimbabwe. This trend has seen the emergence of traditional healers commonly referred to as 'street doctors' especially at public places. Several factors account for this development, namely economic challenges, availability of natural resources, and the user-friendly nature and efficacy of traditional medicine.

\section{Perceptions about Traditional Medicine}

In pre-colonial Zimbabwe, the status of traditional medicine was highly regarded by a symbiotic relationship between the chief and the n'anga (traditional healer). However, the advent of colonial administrators and European Christian missionaries inverted the wheel. The colonial administrators were determined to eradicate the n'anga from the Shona society, considering them as representatives of 'heathen', 'pagan' 'savage' beliefs (Bourdillon 1977: 15). Some prominent scholars, Peresuh and Nhundu (1999) observe that traditional medicine is not talked about openly because of sociological labelling by colonial governments and missionaries, as they attempted to blindly discredit it and replace it with Western medical systems. Waane (1990) states that the processing of traditional medicines is considered unhygienic and unscientific because people are biased against the methods of grinding, pounding, chewing and boiling. Now it seems a large number of families in cities consult traditional healers for their healthcare needs because these practitioners are regarded as accessible, affordable, culturally appropriate and acceptable. They explain illness in terms that are familiar because they are part of the local belief systems (Satima, McBride \& Leppard 1998: 2). 
In our study in Harare it was determined that the traditional healthcare system has maintained its role that is intended to serve the majority of the population of underprivileged people, but has largely been manipulated by unscrupulous and gullible healers swindling people of their savings.

\section{Re-appraisal of Traditional Medicine}

The attainment of independence in Zimbabwe in 1980 saw the government's adoption of a 'generous religious policy' (ter Haar, Moyo \& Nondo 1992: 29) which promoted religious liberty in the country. In line with this policy, Parliament passed the Traditional Medical Practitioners Act in 1981 that saw the reappraisal of traditional medicine in Zimbabwe. As a result, the first Cabinet Minister of Health, Dr Chris Ushewokunze, himself a medical doctor, approved within the medical fraternity, the introduction of a body of traditional medical practitioners called the Zimbabwe National Traditional Healers Association (ZINATHA) on 13 July. Prof Gordon Chavunduka, then Dean of University of Zimbabwe's Faculty of Social Science and later the university Vice-Chancellor, was appointed the first President of ZINATHA. The late Dr Peter Sibanda was then Secretary-General (Shoko 2010: 85). The association sets its aims to unite traditional healers into one body, which would seek to do several things. The first aim would be to promote traditional medicine and practice. Secondly, the association would promote research into traditional medicines and methods of healing as well as promoting training in the art of traditional medicine and spiritual healing. Thirdly, the practice of traditional medicine would be supervised to prevent abuse and quackery and to cooperate with the Ministry of Health and other Ministries and organisations that are involved in the field of public health in this regard. The fourth aim is to preserve and promote beneficial aspects of African culture, and lastly, to cooperate with the Traditional Medical Practitioners Council (Chavunduka 1994: 23). Traditional medical practitioners in Zimbabwe are expected to register and after payment of registration fees obtain certificates and badges as in bio-scientific medicine. This encouragement saw the mushrooming of traditional healing practices in the city (Shoko 2010: 86). As a result, Zimbabwe undertook a major step towards a full recognition of the system of traditional healthcare, first by professionalisation in the form of ZINATHA, a move that facilitated collaboration between the traditional and modern healthcare. 


\section{Tabona Shoko}

\section{Traditional Healers}

There are some 'traditional healers' and herbalists who have sprouted at a number of places such as street corners, pavements, side roads and big high-ways such as Harare's First Street, Julius Nyerere Way, Samora Machel Avenue and Sam Nujoma Streets. Most 'practitioners' of this nature are shrewd and cunning businesspersons who, according to Sekuryu Chitsuwi Banda, 'understand the basic premise of capitalism: supply and demand' (Sunday Mail 9 December 2018).

In their desperate bid to lure clients by pretending to be genuine service providers, some unscrupulous healers wake up early in the morning and go to a nearby wetland and swamps to collect frogs and small tortoise.

He takes these animals home, cleans himself up and takes his catch to his 'factory' at Machipisa Shopping Centre in Highfield suburb. There he gets down to the task of tying colourful beads around frogs and tortoises. He adds rubber bands, horns or chicken nails to the accessories (Sunday Mail 9 December 2018).

By this he imitates a 'goblin', which he supplies to some prophets and self-professed witch hunters (tsikamutanda), who in turn lure their clients on the basis that they would yield immense power to discover and exorcise evil spirits for exorbitant fees. That way the traditional healers attain fake, but brisk business.

Traditional herbs come in various forms such as powder, tree bark soaked in water, or even thick concoctions, which the patient is supposed to drink. Some are root tubers or leaves, such as tsangamidzi. The most popular one is known as guchu, which is believed to be the cure for all ailments, especially sexually transmitted diseases. These herbs come in liquid form. To obtain these, clients sometimes part with a substantial amount of money.

\section{Marketing Strategy}

Among their marketing stunts, the traditional healers allude to the outrageous medical fees being charged by the bio-medical doctors as well as the scaling down of operations at some hospitals. Herbal business is not unique to Harare alone. The trend is reportedly on the rise in dormitory towns such as Chitungwiza, Norton, Bindura and Marondera. Strange as this may sound, a number of people are now familiar with the phenomenon. 
The traditional healer's most common symbol of trade are containers full of concoctions, which they usually wield in their hands and tout as panacea. They utilise all the space they see fit for business and start explaining their herbs. 'Kuruma-ruma kwemudumbu (stomach pains), ulcers, kutema kwemusoro (head-aches), kuzvimba kwetsinga, high blood pressure and diabetes are hammered by the medicine', chanted the herbalist (Sunday Lite Metro 1622 November 2018).

Some healers post conspicuous adverts on buildings and streets with inscriptions, 'ZINATHA Pharmacy Styles Building: Room S6' or 'We Supply Drugs for: HIV-related Symptoms; Blood Purification; Sugar Diabetes; Malaria; Tuberculosis (TB); Cancer; Asthma; Jeko (Menstrual Problems); Kugeza Munyama (Cleansing Misfortune); Mamhepo (Fever); Mhepo yeMudumbu (Constipation); Chomusoro (Headaches); Blood Pressure (BP); Medicine for Luck; Albino Cream; Vuka-Vuka (Sexual stimulants); Sexually Transmitted Diseases (STDs): Syphilis, Herpes and Gonorrhoea' (ZINATHA 2002:$10)$. Through observation, I noticed that numerous state-of-the art traditional healing shrines had sprouted at the nearby Mukuvisi woodlands close to the city centre. Home surgeries are a common sight in the residential suburbs, especially in the high-density suburbs in the city. In some cases noticeboards with words written on them such as Chiremba Pano (Practitioner is here) appear at doors and gate entrances of houses in the suburbs (Shoko 2010: 95)

The healers' marketing gimmick is 'Vachada' (Those who want). They shout, 'Tinawo womusoro, mudumbu' (We have medicines for stomach, headaches, teeth ache). Others shout, 'Uzere pano womutengo wakaderedzwa.' (Medicine is available at reduced prices). At times, they specify the diseases and remedy, 'Vanofufutigwa mudumbu, mamhepo, kugeza munyama isharaude' (Those suffering from constipation, winds, and we cleanse all misfortune). Such traditional healers are very popular and make a large profit by charging reasonable prices for their medicines, and have become known as 'bush doctors' (Shoko 2010: 96).

Favourite hunting grounds for patients are bottle stores, braai places, public toilets and even redundant council beerhalls. Imbibing males are coincidentally the major consumers of the herbs. They are also found at intersections and shop verandas such as TM Hyper and OK supermarkets in Harare, or some frequent places of entertainment such as nightclubs and film theatres. Others mill around flee market areas such as Mupedzanhamo near the Mbare and Avondale shops. Traditional healers have also established markets 


\section{Tabona Shoko}

outside hotels. Restaurants and takeaway shops are not spared street doctors' business. They have also established selling points at bus stations. Both Copacabana and Fourth Street have become harbingers for black-market trade in foreign currency. Yet others spread their herbs at flyovers over and above bridges such as along Chitungwiza and Beatrice Roads. Above all, they have also established bases at the Mbare Musika and Highfields Machipisa marketplaces (Shoko 2010: 96).

Recently ZINATHA has been portrayed in a bad light with some of its charlatan members charging exorbitant fees or conning desperate people seeking medication. Olga Muchadura testified that some ZINATHA members deceived people by raising fatal myths such as 'sleeping with a virgin' as cure for AIDS. On 26 January 2006, the association shocked the people in Harare when they lobbied for the phasing out of condoms because they are 'unAfrican'. However, the government, through the Ministry of Health, spurned the request as ridiculous, 'This is really madness, how can a group masquerading as healers call for the phasing out of protection measures' (Zim Daily 19 February 2016).

Many people have been conned and lost valuable property, money and their lives through the machinations of traditional healers. In a recent case in Murehwa, some $79 \mathrm{~km}$ from Harare, a 7-year-old boy was killed in a ritual murder by his own uncle in connivance with a n'anga. This was based on the false belief that human body parts can boost his uncle's business. The culprits have since been arrested by police (The Herald 1 October 2020).

\section{Herbal Gardens}

The HIV and AIDS scourge has wrought unprecedented negative effects on the health of many Zimbabweans, with many failing to cope with the costs of Western drugs, which are out of reach for many. This has led some traditional healers to be innovative, and in the quest for 'struggle of the fittest', introduced herbal gardens in the city suburbs such as Highfields, Kuwadzana, Budiririro, Glen View, Glen Norah, Mbare, Sunningdale, Dvivarasekwa, Tafara and Mabvuku. The Harare avenue areas have not been spared herbal gardens. People who own herbal gardens, for instance, inhabit flats, such as Trafalgar Court in the middle of the city. Most of these herbs are used to fulfil the role of conventional anti-retroviral drugs. A local gardener reported that 30 people living with HIV and AIDS had graduated with certificates in homebased care 
and herbal gardening (Mutshumayeli Dube 5 December 2018). The trend in Harare is that people who have limited access to anti-retroviral drugs (ARVs) tend to access herbal medicines from traditional healers.

Also faced by skyrocketing prices of life-prolonging ARV drugs, people living with HIV and AIDS and others with chronic diseases such as cancer have turned to the excessive use of traditional medicine under the hands of unscrupulous healers. The uptake of traditional herbal medicine has been compounded by the government's legalizing of mbanje (dagga) farming (The Herald 25 April 2018). Health and Child Care Minister Obadiah Moyo, said the government would not stop any cancer patient from turning to traditional medicine to complement any clinical treatment they were receiving from public health institutions. This buoyed the uptake of herbal medicines. However, the public have abused dagga for smoking for social and entertainment purposes. All this herbal abuse happens despite the government's insistence that it has legalized mbanje or cannabis for medicinal and scientific purposes only.

A rush for herbal medicine in Harare has also been experienced with the introduction of a drug called Gundamiti. This is a herbal concoction produced by the late scientist, Dr Mashava, a University of Zimbabwe lecturer in the Department of Chemistry (The Standard 30 September 2016). The late scientist claimed the drug was sanctioned by the WHO and it could reverse the symptoms of AIDS. As a result, he worked in liaison with Parerenyatwa Hospital to conduct a viral load and CD4 count for his patients. Although his drugs used to be confined to the university campus in Mt Pleasant, many have found their way into the open market in Harare. However, since the death of the practitioner, the drug has become extinct, and thus its efficacy has been questioned. In addition, many other people used to seek help from other traditional medical surgeries such as the one operated by the late Dr Duri, a University of Zimbabwe Chemist who runs his surgery in Harare. In fact, the demise of the traditional medical practitioners-cum scientists has put to question the authenticity of traditional medicine. Other people infected with HIV and AIDS seek help from practitioners at Benjamin Burombo AIDS Clinic, a traditional healer from Kuwadzana suburb, who claims he can cure AIDS. People in need of therapy also access Richard Ngwenya's Immunity Health Centre (IHC) in Harare's avenues. There are several herbal drug stores also found along Simon Mazorodze Road, as well as in many residential suburbs. Gullible Zimbabweans frequent all these traditional medical facilities. Another herb, which comes in the form of a powder, is marketed as a 


\section{Tabona Shoko}

super 'multi-purpose' herb. This herb is popular among chibuku (opaque beer) drinkers, who mix the herb with beer. It is also claimed that the herb boosts men's sexual drive. As soon as one of the guzzlers shouts 'chiremba' (doctor), the herbal vendor immediately responds, 'multi-purpose'. The herbal vendor then explains how his herbs work, 'Any ailment, be it sexually transmitted disease or not, my medicine can cure that. No wonder it is called multipurpose' (Magaisa 12 April 2017). One of the female herbalists had her special types of herbs, which she said enhanced pleasure in bed (Vaida Mlambo 29 June 2017). This is referred to as vhalasheka. Though the herbalist said she did not know the name of the herb, she said it was intended for married people, since it boosted sex drive.

\section{Spiritual Healer}

One of the most interesting cases about gullibility in the health sector involved a religious leader, Walter Magaya, a prophet from Prophetic Healing and Deliverance Ministries, who uses traditional healing methods. He claimed he had found the cure for HIV through a certain tree (called Aguma). He attracted a huge following in the guise of healing (The Herald 30 October 2018). Nevertheless, he has since been arrested for contravening the Medicines and Allied Substances Act, which criminalizes the distribution and advertisement of medicines. All this occurred amidst condemnation by the Ministry of Health and WHO, who have spoken out clearly that so far there is no known cure for the virus. However, despite this retraction, some followers at the service said they paid as much as R200 a month for healing. This kind of leader has managed to sway huge numbers of people in search of healing. Whatever the case, the Magaya's HIV and AIDS cure claims demonstrate the level of gullibility that characterizes Zimbabwe religious and medical landscapes.

\section{Alternate Traditional Medicine}

The city of Harare has also encountered a spiralling wave of alternative medicine, as well as Chinese and Indian medicine, alongside traditional herbal medicine. Perhaps the incursion of Asian medicine has been due to Zimbabwe government's Look-East policy that has been applied subsequent to the Land Reform programme in 2000. There are practitioners of Chinese origin who have established surgeries and medical warehouses that sell traditional medi- 
cine from abroad. Some Chinese shops advertise immunity enhancement programs through drug taking and aromatherapy. They also recruit people to their medical business by organizing membership to medical associations. In addition, they promote aggressive marketing through sales, rewards, and bonuses for best sellers.

Apart from Chinese traditional medicine, the Zimbabwean health market has also been swamped with Indian medicine. In fact, many sick Zimbabwean people are referred to some Indian doctors or specialists in India for treatment. Because of this increasing reliance on the use of traditional medicine in Zimbabwe, the Faculty of Health Sciences at the University of Zimbabwe is considering opening a school of traditional medicine in Harare that will offer training for medical students and supply traditional medicines in their hospitals for treatment. In addition, Zimbabwe has opened a clinic for traditional Chinese medicine in Harare (The Herald 25 September 2020). ZINATHA also offers a certificate on traditional medicine in Harare. All these factors, though with noble intention, tend to influence some gullible Zimbabweans to fall prey to charlatans in traditional medicine. Nevertheless, what is important is to sift the good from the bad operations of traditional healers.

\section{Negative Attributes of Traditional Healers}

The negative portrayal of traditional healers dates back to Western stereotypes of Africa and its people, in particular missionaries, who viewed traditional healers as 'witchdoctors', who reside on the 'dark continent'. With such a colonial and Christian-centric mindset, traditional healers are largely viewed by Harare residents as bad economic opportunists bent on exploiting the public. In an interview some people told us that traditional healers had abused them. A community leader explained that 'a traditional healer will try to beat a patient, because always they associate any kind of ailment, like demon possession, and sometimes like a spirit has gotten into you' (Vaida Mlambo, Harare 15 March 2017).

Traditional herbalists, particularly those that ply their trade in the streets in Harare, are often viewed as leading a life that resembles that of 'street kids'. Swart (1990: 92) sums up the work of 'street kids' as limited to four categories; begging, theft, scavenging and odd-jobbing. For most healers of this type, medicines are stuffed in tins, bottles or wrapped around plastic bags or pieces of cloth. They do this in order to avoid arrest for illegal vending by 


\section{Tabona Shoko}

law enforcement agents. Nevertheless, the Zimbabwe government sees them as an embarrassment and sweeping arrests are mounted by the police. Likewise, healers complain of police harassment as exemplified by someone, 'It is very bad. We are arrested for no reason. People were rounded up and sentenced to three years for no offence' (Bourdillon 1991: 28).

Maclean and Fyfe (1986:11) note that some traditional practices are clearly beneficial and harmless, but others are injurious and could imperil an acutely ill person or child. A Harare man is said to have gone mad a week after drinking a concoction called mudzepete. A traditional healer in Mufakose administered the concoction in an attempt to intervene on behalf of a man whose wife was involved in infidelity (The Daily Mirror 4 June 2016). Tsitsi Matope, a woman who resided in Dzivarasekwa in Harare died a few months after a traditional healer from Mbare suburb administered a lethal injection. The healer was attempting to treat some sexually transmitted disease. A postmortem revealed that Tsitsi had died of anaphylactic shock and drug reaction (The Herald 4 November 2017).

In our study, we noted that people are also more inclined to try a more traditional approach to medicine, especially when some practices are supported by their culture or religion. This is prevalent in communities riddled with poverty, corruption, and violence such as the context of Harare. This is especially the case when dealing with sexual ailments. However, one biomedical specialist pointed out, 'Herbal medicines can cause kidney failure and liver damage in some consumers because they contain toxic chemicals or heavy metals, or react harmfully with other drugs' (Magaisa, Harare 14 July 2018). For some HIV-infected patients on ARV treatment, the use of traditional medicine can reverse the positive gains of the drugs.

According to one Medical Research Journal, the very nature of it being unregulated is already a big red flag for would-be buyers, as nobody can really tell the components of these herbal medicines or the extent of its effects. It isn't supported by sufficient clinical trials and studies that can ease our worries over potential side effects or adverse reactions (The Guardian 2018). Those are just some of the valid reasons raised by medical experts regarding the challenges of supporting traditional medicine.

In this light, many Zimbabwean healers have caused untold suffering and death amongst their gullible clients of traditional medicine. However, it will be unjustified to depict the traditional healers and medicine as solely negative; there are some other positive aspects associated with this medical facility. 


\section{Some Positive Aspects of Herbal Medicine}

Although traditional healers and their clients are gullible pertaining to the use of traditional medicine, there are some positive aspects about the use of traditional medicine. One thing that makes traditional medical specialists attractive is the fact that they are able to give more personal attention to patients than is possible at larger and busy bio-medical hospitals. In that respect, traditional medicine has become a popular means of improving health for the majority of the people in Harare. Our study has found that bio-medicine could not meet the health needs of the people in Harare and that available funds were not adequate to provide healthcare for all. Because of this, many people have become interested in traditional medicine as a way to strengthen their health. A traditional healer, Moven Kalindawaro, concurs, 'Herbs are effective and usually provide food in itself. Remember our forefathers used to eat wild plants or herbs' (Kalindawaro2017). This stance shows that herbs are effective in the lives of some people.

The fact is that the Shona depended upon traditional medicine for their health long before the introduction of bio-medicine prolonged their lifespan. This makes it valid that the herbs are effective, and besides, people who use them believe that the herbs are affordable. In addition, the fact that traditional medical practitioners who use traditional medicine attend to many people who approach them makes the medicine user-friendly. As a result, people easily turn to traditional herbs whenever they encounter problems or sickness.

Dr David Parirenyatwa, Zimbabwe's former Minister of Health, said in an endeavour to promote the use of traditional medicine, the Assembly of the Organization of African Union) (OAU) now the African Union Authority (AUA) heads of state and government summit in July 2001 declared the period $2001-2010$ as the decade for African traditional medicine (The Herald 24 September 2017). They also agreed to commemorate the African Traditional Medicine Day on 31 August every year as strategy to promote the use of traditional medicine. All this suffices to say traditional medicine has some value that is recognised internationally.

\section{Conclusions}

This paper has shown that the attainment of Zimbabwe's independence in 1980 has ushered in the reappraisal of traditional medicine. As a result, there has a swing towards the use of traditional medicine to support people's health. The 


\section{Tabona Shoko}

hyper-inflationary whirlwind that has reached Zimbabwe has recently seen a number of hospitals scaling down operations. Coupled with this is the people's general desire to seek alternative health services from other providers in the wake of exorbitant medical fees that some bio-medical doctors demand. Against this backdrop, some unscrupulous traditional healers have emerged who deceive people out of their hard savings in an effort to seek healthcare. The paper has argued that some traditional healers are misleading gullible members by claiming they have the capacity to cure complex diseases such as cancer and AIDS. Moreover, they employ all sorts of marketing strategies to attract people to their healing facility. Of late, Chinese and Indian medicines entered the market, thereby increasing the gullibility of people. Nevertheless, traditional medicine has some positive and negative effects. The First Lady, amai Auxillia Mnangagwa, hammers the point home by urging pharmaceutical industry regulators to tighten their surveillance and monitoring systems to protect gullible patients from fake medicines.

\section{References}

Bourdillon, M.F.C. (ed.). 1977. Christianity South of the Zambezi. Volume 2. Gweru: Mambo Press.

Chavunduka, G. 1994. Traditional Medicine in Modern Zimbabwe. Harare: University of Zimbabwe Publications.

Maclean, U. \& C. Fyfe 1986. African Medicine in the Modern World. Edinburgh: Centre for African Studies.

Peresuh, M. \& T. Nhundu 1999. Foundations of Education for Africa. Harare: College Press Publishers.

Satima, F.T, S.R. McBride B. \& Leppard 1998. Prevalence of Disease in Rural Tanzania and Factors influencing the Choice of Health Care, Modern or

Traditional. ARCH Dermato 134: 10-25.

https://doi.org/10.1001/archderm.134.11.1363

Shoko, T. 2010. Traditional Healing in Harare: Continuity and Change. In Togarasei, L. \& E. Chitando (eds.): Faith in the City: The Role and Place of Religion in Harare. Uppsala: Swedish Science Press.

Swart, J. 1990. Malunde: Street Children of Hillbrow. Johannesburg: Witwatersrand University Press.

Ter Haar, G., A. Moyo \& S.J. Nondo 1992. African Traditional Religion in Religious Education. Utrecht: Utrecht University. 
Waane S.A.C. 1990. The Use of Traditional Medical Plants: The Cultural Context. Proceedings of International Conference on Traditional Plants. Arusha: Dar Es Salaam University Press, Ministry of Health, Tanzania.

\section{Interviews}

Dube, M. Interview 5 December 2018.

Magaisa, B. Interview 12 April 2017.

Kalindawaro, M. Interview 15 January 2017.

Mlambo, V. Interview 29 June 2017.

\section{Newspapers}

Sunday Lite Metro, 16 - 22 November 2018.

Sunday Mail, 9 December 2018.

The Daily Mirror, 4 June 2016.

The Guardian, 2018. https://www.theguardian.com/australia-news/2017/feb/ 06/herbal-medicines-can-have-dangerous-side-effects-research-reveals (Accessed on 3 December 2018.)

The Herald, 24 September 2017

The Herald, 4 November, 2017.

The Herald, 25 April 2018.

The Herald, 30 October 2018

The Herald, 25 September 2020.

The Herald, 1 October 2020.

The Insider, 5 September 2018

The Standard, 30 September 2016.

Zimbabwe Situation, 30 June 2016.

Zim Daily, 19 February 2016.

Zimbabwe National Statistics Agency, (ZIMSTAT), 2009, https://www.bing.com/search?q=ZIMSTAT+2009+land+reform

Prof. Tabona Shoko Department of Religious Studies, Classics and Philosophy University of Zimbabwe Harare shokotab@yahoo.com 